\title{
総説
}

膀胱癌の悪性度・浸潤性判定のための細胞生物学的アプローチ

\author{
慶應義塾大学医学部泌尿器科学教室 \\ 橘政昭
}

\section{CELLULAR BIOLOGICAL APPROCHES FOR DETERMINING OF MALIGNANT POTENTIAL AND INVASIVENESS OF BLADDER CANCERS}

\author{
Masaaki Tachibana \\ Department of Urology, School of Medicine, Keio University
}

\section{はじめに}

膀胱移行上皮癌は grade-1，表在性腫瘍のような極 めて予後の良好なものから, grade-3浸潤性腫瘍のよう な予後不良なものまで，その悪性度・浸潤性は幅広い スペクトラムを有することは周知の事実である ${ }^{122)}$.し かしながらこれら悪性度あるいは浸潤性を規定する因 子は現時点においては形態学を中心とした組織学的検 討が中心であり未だ一般的に臨床応用するに足る指標 が存在しないのが現状であると言わざるを得ない．本 稿では，膀胱移行上皮癌における悪性度・浸潤性を規 定する基礎的ならびに臨床的事項を review し，今後 の展望を探ることとする.

\section{表在性膀胱癌の自然史}

一度, 膀胱内に腫瘍の存在が証明されると, それが 極めて小さく，かつ単発で grade-1の移行上皮癌で あったとしても，その後の患者の予後を予想すること は困難であると言える，その最大の理由は膀胱癌にお いてはその多くが種々の間隔をもって再発を繰り返 し，その間に腫場悪性度の増悪を来し，時には膀胱全 摘術を余儀なくされる場合あるいは転移性病変を来す 症例も少なくないからである ${ }^{3)}$. 一方, National Bladder Cancer Group の報告によれば, 多くの筋層浸潤膀 胱癌は診断の最初から筋層浸潤癌であることが示され ている ${ }^{4)}$.また, 表在性腫瘍の浸潤性の予測に関しては 腫瑒悪性度が最も信頼しえる指標となっている，例え

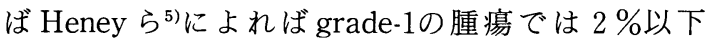
に，また grade-2では $11 \%$ ，さらに grade-3では $45 \% に$ 筋層浸潤を伴う progression が最初の診断より 2 年の 内に生じることが報告されている.さらには, 30～50\% の grade-3, pT1腫瘍はその後の経過中に筋層浸潤や
遠隔転移を生じることを報告している(6) 99. しかしな がら，これら組織学的悪性度の判定はかならずしも単 純ではなく, 単一な grade の腫瘍細胞が均一に存在す るとは限らず, 実際には種々の grade の腫瘍細胞が混 在しており, 正確に grading を行うには困難を伴うこ とが多いのが現状であると言えよう。ごく最近, Kakizoe ら ${ }^{10)}$ により膀胱癌の進展および転移の細胞生物 学に関する review が報告されており, 膀胱癌の生物 学的特性の理解に有用であろう.

\section{染色体解析}

膀胱癌腫瘍組織における染色体解析に関する報告で は, 染色体の数が通常と異なる数的異常と, 染色体の 転座や欠損などの質的異常があり, これら染色体解析 によるその異常は腫瘍の浸潤性および予後を規定する 因子として極めて重要であることが示されている11). 最近, restriction fragment length polymorphism (RFLP) 解析法により軽微な遺伝子欠損を細胞遺伝子 学的手法より高率に検出することが可能となった ${ }^{12)}$. この手法により対立遺伝子の欠損は loss of heterozygosity (LOH) として補えられる ${ }^{13)}$.これら遺伝子 欠損として膀胱癌では chromosome 3p, 9q, 11p, 13 $\mathrm{q}, 17 \mathrm{p}$ ，および18q の欠損が報告されている ${ }^{12) \sim 14)}$.ま た, chromosome 9q の欠損は膀胱癌進展の比較的早期 に認められる頻度の高い異常であるとする報告があ $3^{14)}$.さらには $17 \mathrm{p}$ の欠損は約 $70 \%$ の進行膀胱癌症例 に認められたとする研究は ${ }^{14} \mathrm{p} 53$ 癌抑制遺伝子の存在 する染色体がこの部分であることからも極めて興味深 い.この他, chromosome 5の短腕の isochromosome, chromosome 7の trisomy あるいは chromosome 9の monosomy などの膀胱移行上皮癌に特異的な染色体 
異常が報告されている1114).

染色体の数的異常について最近は in situ hybridization 法を用いて比較的簡便に特異的な染色体の数的 異常を検出することが可能となり，これら検討より染 色体 7 番と 17 番の数的異常が癌細胞の悪性度および深

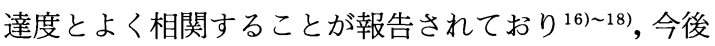
の臨床応用が期待される.

\section{形態計量（モルフォメトリー）}

コンピューターを使用した画像解析装置を用いて腫 瘍細胞の形態を客観的に解析しようとする試みがなさ れている ${ }^{1920)}$. 核面積, 核の円周, 細胞質面積を求め, 平均核面積 (mean nuclear area NA), NA の標準偏 差（SD of NA，SDNA），などの客観的細胞形態計測 值が腫瘍の組織学的悪性度と良好に相関することが報 告されている. 非乳頭状腫瘍は乳頭状腫瘍に比較して 2 倍の nuclear variables が認められ，また grade-3腫 瘍は grade-1腫瘍に比し同様に 2 倍の nuclear variables が認められたとする報告がある20221).さらには表 在性腫瘍の進展は上述の NA あるいは SDNA と密接 に関連すること，またリンパ節，遠隔転移は nuclear variables の大きな腫腸に高率に認められることが報 告されており ${ }^{20122}$ 膀胱癌の客観的悪性度評価法として 注目されている。また平均核面積の大小と患者生存率 は密接に相関し, 予後予測因子としての臨床的意義も 報告されている ${ }^{21) 231}$. しかしながら, 従来の組織学的 検索, フローサイトメトリー, およびモルフォメトリー を対比した検討では, 乳頭状腫瘍におけるモルフォメ トリーの予後因子としての有用性には限界があること も指摘されている ${ }^{24)}$. 肉眼的観察をより客観的に表現 するという意味では有効な方法であるが，予後予測因 子としての信頼性については今後のさらなる検討を要 するものと考えられる.

\section{フローサイトメトリー}

多くの癌においてその染色体の異常が腫瘍の増殖性 あるいは浸潤・転移性を判断するひとつの指標となり 得ることが報告され，その解析の方法の一つとして flow cytometry (FCM) の応用が各種の悪性腫瘍にお いて検討されてきた. FCM は多数の細胞集団の genetic content を短時間に測定できることより，細胞 生物学および臨床医学への応用が急速になされたもの の一つといえる。特に核 DNA 量の解析は癌細胞の細 胞生物学的特性を反影するものとして多くの注目を集 めた。しかしながら，FCM の適応は単に細胞核の DNA 量の測定のみならず他のパラメーター，例えば
膀胱癌関連抗原の同定，増殖期細胞に特異的なマー カーの観察など多項目を同時に解析し得る可能性を有 しており，今後癌浸潤性に関連するより有力かつ特異 的なマーカーの開発により更にその有用性は増すこと が予想される．本項では膀胱癌における DNA ploidy 解析を中心にその現状を述べる。

一般に FCM によるDNA histogramはDNA diploid とDNA aneuploid とに分けて論じられるのが 通常である. Barlogie ら ${ }^{25}$ は4,900におよぶ腫崵細胞 の DNA ploidy 解析を行い原発腫瘍と転移性腫瘍の 評価よりDNA aneuploid腫場のより aggressive な 生物学的傾向を明らかにした．膀胱癌においては組織 学的に high-grade あるいは high-stage の腫瘍におい て高率に DNA aneuploid が認められ膀胱癌悪性度診 断上，また予後因子として極めて重要な検査法である ことが報告されている2627).

事実, grade-3の膀胱癌では60 80\%に DNA aneuploid が認められるのに対し，grade-1腫瘍の70〜80\% は DNA diploid を示し，T4腫瘍の70\%は DNA aneuploidに対し Ta-T1腫瘍の70\%が DNA diploidであ ることが示されている ${ }^{28) ~ 30)}$.

またDNA aneuploidがリンパ節転移あるいは遠隔 転移における有用な予後因子となり得ることが報告さ れている.つまり DNA aneuploid 腫晹は diploid 腫瘍 に比し高率にリンパ節転移あるいは遠隔転移を有する ことが示されており ${ }^{28299}$ ，その当然の結果として DNA aneuploid 腫瘍の予後が diploid 腫瘍に比し不 良であるとする報告が多くなされている22223228) 33).

一方，FCM によるDNA ploidy 解析は病理組織学 的評価以上の予後因子としての情報をもたらすもので はないとする意見もある。例えば Murphy ら ${ }^{34)}$ は，63 例の膀胱癌症例の検討よりフローサイトメトリーによ る DNA ploidy 解析は組織学的悪性度診断を凌駕す る予後因子とはなっていないことを報告している。さ

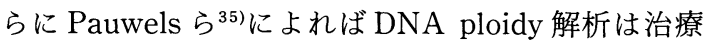
方針決定の判断材料にするほどには信頼性のある検査 方法であるとは言い難いと結論している，相反して， deVere White $ら^{36)}$ はNA histogram は組織学的悪 性度・深達度を凌駕する予後因子として有用であると 結論している.著者らの検討では203例の膀胱癌症例に おける予後を腫湟の grade, stage の組織学的指標と 各種 $\mathrm{FCM}$ 上の parameter を多変量解析で詳細に解 析したところ，4n 以上の DNA 含量を有する hypertetraploid を $5 \%$ 以上有する群における予後への関与 
図1 フローサイトメトリーによる膀胱癌組織の DNA histogram.

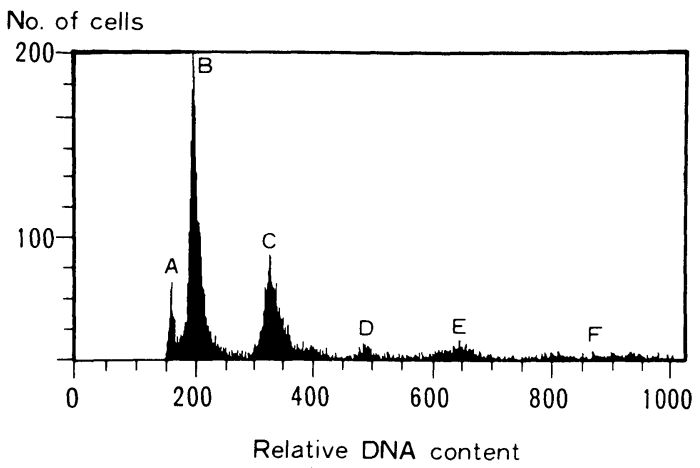

図 2 膀胱癌症例の hypertetraploid の有無による生 存率.

HT : hypertetraploid

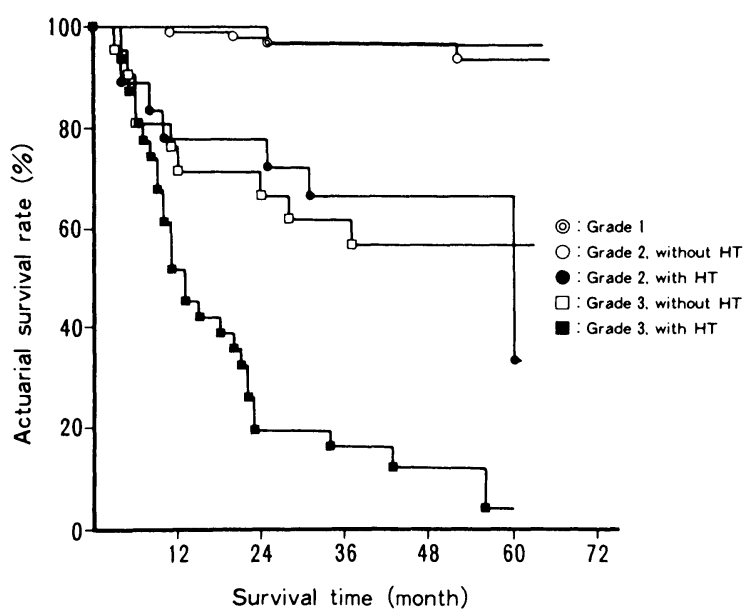

は組織学的悪性度と同様の最も重い寄与を認め, つぎ に4nの DNA 含量を持つ tetraploidyを示す細胞を 10\%以上有する群ではそれにつぐ予後因子として重要 であったことが認められた ${ }^{37)}$.さらにこの hypertetraploid の有無により一般的に予後不良とされる grade3腫瘍の予後が比較的明確に区別できる可能性が示さ れた.ここでもう一つ重要なことは, 通常の DNA histogram の判定法である DNA index（明らかな 2 つ $\mathrm{G} 0+\mathrm{G} 1$ ピークを有するか否か)では組織学的判定を凌 駕する予後因子としては認められなかったことであ る.つまりフローサイトメトリーによる DNA histogram 上の異常をどのように判定するかの一致した意 見が現在まだ確立しておらず, 異なる見解が生じる結 果を招いていることが予想される.いずれにしても膀
胱癌において DNA diploid を示す腫瘍の予後が良好 なことは多くの施設において一致した見解である。吉 川ら ${ }^{38)}$ は94例の膀胱癌症例の予後と DNA ploidy を検 討し, 癌死例 8 例, 担癌生存例 5 例のいずれの症例も DNA aneuploidy であり, DNA diploid 症例の予後が 良好であることを報告している8).このように DNA ploidy 解析に対する異なる見解が生じる原因として まず第一に腫瘍における heterogeneity（異質性）が挙 げられる.Lipponen らは DNA ploidy の腫瘍内 heterogeneity は細胞生物学的多クローン性と手技的要因 によることを指摘している ${ }^{39)}$. 第 2 点として腫瘍内の 著明な炎症性細胞浸潤は腫瘍の aneuploid ピークをマ スクし DNA diploid と誤認する結果を生じる可能性 が指摘されている ${ }^{10)}$.

このような現状で, 膀胱癌に対するフローサイトメ トリーによるDNA ploidy解析の意義に関して Wheelessらにより ${ }^{41) “ C o n s e n s u s ~ r e v i e w ~ o f ~ t h e ~ c l i n i-~}$ cal utility of DNA cytometry in bladder cancer” と題 した論文が発表されている。彼らは膀胱癌の DNA ploidy 解析に関する代表的な論文を多数評価した上 で，現状におけるとらえ方の指標を示したもので，こ こでの一つの結論として, 表在性膀胱癌 (Ta, T1, TIS) におけるDNA ploidyとその進展の危険性において は, 複数の DNA aneuploid population の存在>一つ の DNA aneuploid population の存在 $>$ DNA tetraploid population $の$ 存在 $>$ DNA diploid population の順でより大きな危険因子と考えるのが妥当であるこ とが示されている.しかしながら，一方において T2〜T4の浸潤癌においては治療方針決定の根拠とす るような情報をもたらすものと断定し得るものとは なっていないと結論し, 今後のさらなる検討が必要で あるとしている。

フローサイトメトリーによる DNA ploidy 解析が 一般的な膀胱癌の悪性度判定基準としてさらに広く臨 床応用されるためには, 今後, 統一された DNA ploidy の判定基準の整備とともに DNA ploidy解析を補助 するさらに腫瘍に特異的なマーカーを同時に解析する などの研究が必要であると考えられる。

\section{細胞増殖性}

癌細胞におけるその増殖性の検討は細胞の DNA 合 成能が直接的に癌の増殖進展に関連することよりその 予後を検討する上で極めて重要であると言える. Meyer ${ }^{42)}$ は数多くの腫瘍細胞における増殖性の検 討より, 細胞増殖と癌の浸潤性が極めて密接に関連す 
表 1 膀胱癌組織におけるフローサイトメトリーを使用した bromodeoxyuridine 標識率

\begin{tabular}{c|c|c|c|c}
\hline Disease & Grade 1(No.) & Grade 2(No.) & Grade 3(No.) & Totals(No.) \\
\hline Superficial & $5.3 \pm 2.7(11)$ & $6.7 \pm 5.2(38)$ & $11.1 \pm 7.9(7)$ & $6.9 \pm 5.5(56)$ \\
Muscle-invasive & - & $20.9 \pm 12.9(3)$ & $16.5 \pm 8.0(22)$ & $17.0 \pm 8.5(25)$ \\
\hline Totals & $5.3 \pm 2.7(11)$ & $7.7 \pm 8.9(41)$ & $15.2 \pm 8.2(29)$ & $10.0 \pm 8.0(81)$ \\
\hline
\end{tabular}

High grade and muscle c-invasive tumors tended to have a larger bromodeoxyuridine labeled cell index.

ることを報告している．しかしながらこれらの従来の 検討においては, S 期細胞に選択的に取り込まれる thymidine ${ }^{3} \mathrm{H}$ を中心した放射性物質により標識 しその増殖性を検討する方法が主体であった。最近に なり，これら細胞增殖に関連する物質あるいは抗原が 明らかにされ，これら物質を応用した癌細胞の増殖性 の観察が行われるようになった。これらの物質には proliferating cell nuclear antigen (PCNA), DNA polymerase- $\alpha$, Ki-67, そして bromodeoxyuridine な どが挙げられる. Lipponen らはPCNA の免疫組織染 色の結果と膀胱移行上皮癌の予後とは密接な関連が あったことを報告している。

1982年, Gratzner ら ${ }^{43)}$ は thymidine の analogue で ある bromodeoxyuridine に対する抗体を開発し，こ のことは従来放射性物質を使用した thimidine の取り 込み率の検討をより容易に行うことを可能とし，特に 最近ではフローサイトメトリーを用いたより客観的な 細胞増殖動態の解析方法として注目されてい $ろ^{44) \sim 46)}$. 著者らは bromodeoxyuridine (Brd U) をin vitro において腫瘍細胞に標識し, フローサイトメト リーにより標識率を求め膀胱癌の悪性度・浸潤性との 対比あるいは予後との関連を検討した ${ }^{47) \sim 99}$. 81例の膀 胱癌の検討において，11例の grade-1症例における BrdU 標識率は $5.3 \pm 2.7 \% ， 41$ 例の grade-2症例では $7.7 \pm 8.9 \%, 29$ 例の grade-3症例では $15.2 \pm 8.2 \%$ あ り膀胱癌全体の平均は $10.0 \pm 8.0 \%$ であった.また, 表 在性膀胱癌 56 例の $\mathrm{BrdU}$ 標識率は6.9土5.5\%であっ たのに対し,25例の筋層浸潤腫瘍では $17.0 \pm 8.5 \%$ あ り, 筋層浸潤性腫瘍の BrdU 標識率は有意に高値を示 した。これを grade-1の BrdU 標識率の平均＋2SD で ある $10.7 \%$ 区別してその予後を検討すると，51例の 低 $\mathrm{BrdU}$ 標識腫瘍の 3 年生存率は $98.0 \%$ でったの に対し, 30例の高 BrdU 標識腫瘍のそれは $42.9 \%$ と BrdU 高標識腫瘍の予後は不良であった.さらに,これ を grade-3腫瘍に限って検討すると， 7 例の低 BrdU
図 3 Grade-3膀胱癌症例の bromodeoxy-uridine 標 識率の差による予後の検討.

BrdU-LI : bromodeoxyuridine 標識率

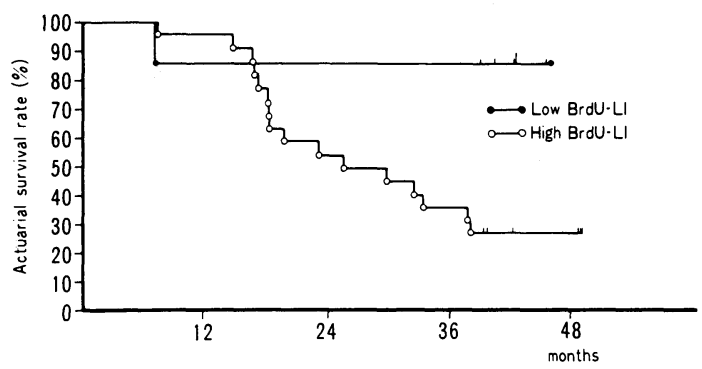

図 4 組織学的悪性度と bromodeoxyuridine 標識率 によるスコア別生存率.

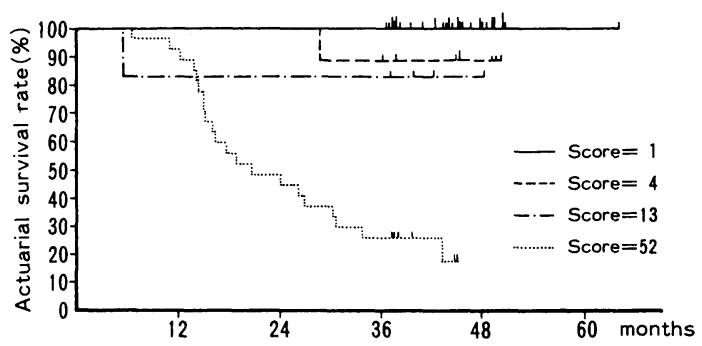

腫瘍の 3 年生存率は $85.7 \%$ に対し, 22 例の高 BrdU 腫 瘍のそれは $27.3 \%$ と, grade-3腫瘍の予後を BrdU 標識 率により区別し得る可能性があるものと考えられた。 さらに, 著者らは BrdU 標識率と組織学的悪性度より 膀胱癌のスコアリングを試みた ${ }^{50)}$.このスコアリング で最も低值の膀胱癌症例では 3 年生存率は $100 \%$ で あったのに対し最も高スコアを呈した症例の 3 年生存 率は $17.3 \%$ との予後は極めて不良であった。これら 結果より膀胱癌の細胞増殖はその予後と極めて密接に 関連することが予想される。

BrdU と同様に細胞の増殖性を検討するマーカーと $し て$ proliferating cell nuclear antigen (PCNA) が 
挙げられる。PCNA は1987年 Miyachi ら ${ }^{51)}$ が SLE 患 者血清中の自己免疫抗体の核内抗原に対して命名し, その後, 増殖期の細胞に出現する核蛋白として同定さ れていた cyclin と同一物質であることが明らかにさ れた. DNA polymerase- $\delta$ の補助蛋白であり, DNA 合 成に深く関与し, 細胞周期の late G1から $\mathrm{S}$ 期に発現 が認められるとされている. PCNA はパラフィン包埋 標本においてもその検討が可能なことより病理組織像 との対比が容易である ${ }^{52)}$. Lipponen $~^{53)}$ は178例の膀 胱移行上皮癌を検討し, PCNA の陽性染色率は浸潤癌 で高値であり, 表在性膀胖癌の予後因子として有用で あることを報告している．同様に Hattori $ら^{54)}$ も膀胱 癌における PCNA 標識率の測定は膀胱癌浸潤性の指 標および予後因子として有用であることを示してい る.

増殖期細胞の指標として Ki-67の研究も数多く報告

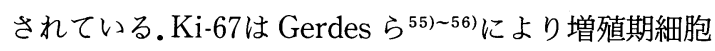
関連蛋白に対する抗体として開発され各種細胞の増殖 性の研究に用いられて来た. Ki-67陽性細胞は G1，S， $\mathrm{G} 2 / \mathrm{M}$ に広く分布し, mRNA 合成のための DNA 複製 の際に必要な酵素と考えられており, resting cell (G0) 以外の細胞においてはその存在が認められる. Fontana ( $^{57)}$ は膀胱癌101症例に対し Ki-67に対する 抗体による免疫組織染色の検討を行い Ki-67陽性細胞 と組織学的悪性度とは極めて密接な関連があることを 報告している。さらに彼らは, Ki-67陽性細胞の腫瘍組 織内での分布を検討し, 浸潤癌においては腫瘍基部を 中心に腫瘍全体に分布するのに対し, 表在性癌におい ては表層部を中心に分布していたとしている.Tsujihashi $~^{58)}$, Bush $5^{59)}$ も Ki-67の膀胱癌浸潤性規定因 子あるいは予後因子としての有用性を報告している.

さらに, 細胞増殖のマーカーとして核小体形成体関 連蛋白である argyrophilic nuclear organizer region associated protein (AgNOR) が細胞增殖と関連する ことが多くの臓器において報告されている AgNOR は RNA polymerase 1による rDNA 転写活 性の指標と考えられており, 細胞増殖能の六進した細 胞核内では核小体の解離が起こり, AgNOR が分散し, AgNOR 数の増加として観察される. 他の増殖性マー カーと同様に high-grade, high-stage の膀胱癌におい てその数が増加する傾向が報告されている ${ }^{6162)}$. さら にAgNOR は表在性膀胱癌の進展あるいは予後と密 接に関連するが非乳頭状増殖を示す膀胱癌における有 用性は少ないことが報告されている ${ }^{63)}$.さらに興味あ
る報告として, 移行上皮癌においては AgNOR 数は c-erb B2蛋白の発現と密接に関連し, c-erbB-2発現の 有無と細胞増殖の差が示されている ${ }^{63)}$.

これら 3 種の細胞増殖マーカーを膀胱癌において比 較検討した報告がある ${ }^{64)}$.ここでの知見として, BrdU 標識率と Ki-67, PCNA 標識率とは有意な相関が認め られたが, BrdU 標識率と AgNOR との間には有意な 相関が認められなかったとしている。 また, これら細 胞増殖マーカーは腫瘍の組織学的 grade と相関する ものの stage との相関は乏しかったことを報告してい る.

この他, 最近の molecular biology の発展に伴い, syk, c-fyn, c-lyn, c-fgr, c-yes など細胞増殖あるいは シグナル伝達に関連する各種の oncogene product に 対する抗体が開発され臨床との対比が進められている のが現状である.

いずれにしろ, 膀胼癌細胞の増殖活性がその浸潤性 あるいは悪性度と密接に関連することは事実である. しかしながら, 現時点において, はたしてこのことが 癌細胞の特性として発現しているのか, あるいは種及 の要因の結果を捉えているのかは明らかではなく，今 後これら増殖性を規定する要因のさらなる解析により 客観的な細胞生物学的特性の指標として臨床応用の可 能性が期待される。

\section{膀胱癌細胞における特異物質の産生と浸潤性}

膀胱癌細胞の多くをしめる移行上皮癌は比較的特徵 に乏しい細胞であるが，いくつかの特異的蛋白の産生 が古くより報告されている。

Human chorionic gonadotropin (hCG) ${ }^{65)}$, fibrinolytic protein $^{66)}$, angiogenic factor ${ }^{67)}$, prostaglandin ${ }^{68}, \mathrm{CEA}^{69)}$, epithelial membrane antigen ${ }^{70)}$ あ るいは human B-cell differentiation factor ${ }^{71) さ ら に ~}$ は各種 hematopoietic cell growth factor の産生 ${ }^{72) 73)}$ が証明されている.特に hCG については悪性度あるい は浸潤性の高い腫瘍においてその発現が認められると する報告が多い. Shah ら ${ }^{74)}$ によれば grade-1，-2の移 行上皮癌における hCG の検出率は41症例中 0 であっ たのに対し, grade-3，-4では56例中12例と高率に検出 されたことが報告されている。同様に Campo ら ${ }^{75)}$ high-grade の移行上皮癌における hCG の高い検出率 を報告している。一方, Dexeus ら ${ }^{76)}$ は血清 $\beta$-hCG レ ベルの検討を92例の進行移行上皮癌症例に行った結 果, $\beta$-hCG 值が高值を示した症例の化学療法の反応性 は不良であり治療の反応性あるいは進展を予想する上 
図 5 膀胱癌組織に対する抗 G-CSF 抗体による免疫組織染色. 膀胱癌細胞に陽性染 色所見が認められる.

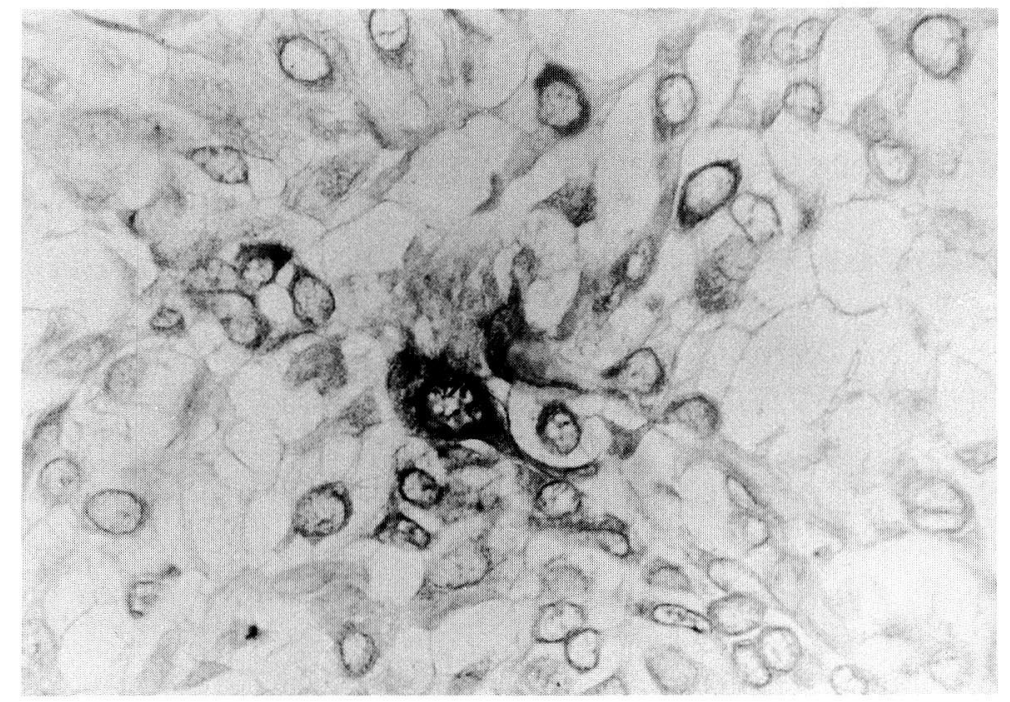

で有用であるとしている.また，彼らは進行尿路上皮 癌症例における carcinoembryonic antigen (CEA) お よび $\beta$-hCG の血清值を測定し, 16例(17\%)にCEA 值 の高值を，また13例 $(14 \%) に \beta-h C G$ の高值を,さら に 6 例（6\%）に両者の高值を認め，これらマーカー が症例の予後あるい㳊化学療法に対する反応性を判断 する指標となり得る可能性を指摘している。しかしな がら，多くの症例ではたと京度浸潤癌であっても， これら腫瘍マーカー值は正常であり, progressionを したとしても,マーカー値が高值を呈することはなく， 尿路上皮細胞の CEA あるいは hCG 産生と腫瘍浸潤 性とはかならずしも関連を認めないのが通常である。 Smith ら ${ }^{77}$ は163例の膀胱全摘術を施行した症例の血 清 $\beta$-hCG 值を測定し病理組織診断における grade と stage を検討した。 その結果 $10 \%$ の患者に $\beta$-hCG の高 值が認められたものの腫瘍の grade, stage, 予後との 関連は認められなかったことを結論している。

今後これらマーカーの発現機序の解明がその浸潤性 との関連を検討する上で不可欠であると考えられる。

\section{増殖因子と癌の増殖}

各種增殖因子は細胞表面の特異的 receptor と結合 し増殖に関する各種活性を惹起する，癌細胞において はときとしてこれら増殖因子ないし増殖因子 receptor の異常産生あるいは異常発現をし, 異常な細胞増 殖を生じる可能性がある.

Epidermal growth factor (EGF) は分子量6,000の
蛋白で唾液腺, 胎盤, 前立腺, 遠位尿細管, 血小板な どの正常細胞において産生されていることが知られて いる ${ }^{78779}$.この EGF receptor (EGF-R) は多くの上皮 細胞に存在し, EGF の receptor への結合は EGF-R の tyrosine kinase 活性を刺激し, その signal 伝達の initiation を起こすことが知られている80).

EGF は上卜尿中に多量に排出されて打り, 正常尿路 上皮はもとより尿路癌も常にこの EGF の暴露を受け ていることになる.Kuranami ら ${ }^{81}$ は七卜正常尿が移 行上皮癌細胞の増殖を穴進する事実を報告している. また興味ある研究として, rat 膀胱癌モデルを使用し, 異なる部位に移植した腫湯が正常 rat の尿中 EGF に より promoteされることが示されている82831.さらに Messing らのグループ84) は膀胱癌症例の尿中 EGF 濃 度を測定した結果, 膀胱癌症例では正常コントロール に比較して有意に EGF 濃度が低下していたことを報 告している.

一方，EGF-R に関しては，免疫組織染色あるいは autoradiography によるEGF-R 発現が研究され，正 常尿路上皮に比し癌細胞に EGF-R の発現が増加して いること，また high-grade あるいは invasive 腫場に おいて顕著であることが示されている85). Messing $ら^{86)}$ は EGF-R の分布は正常尿路上皮では基底層の細 胞を中心に存在するのに対し，悪性あるいは異型性の 部分では全体的に分布することを報告している。ここ での最大の興味は EGF-R は予後不良症例において顕 
図 6 ヒト膀胱癌培養細胞におけるRT.PCR による G-CSF および G-CSF receptor mRNA の同定.

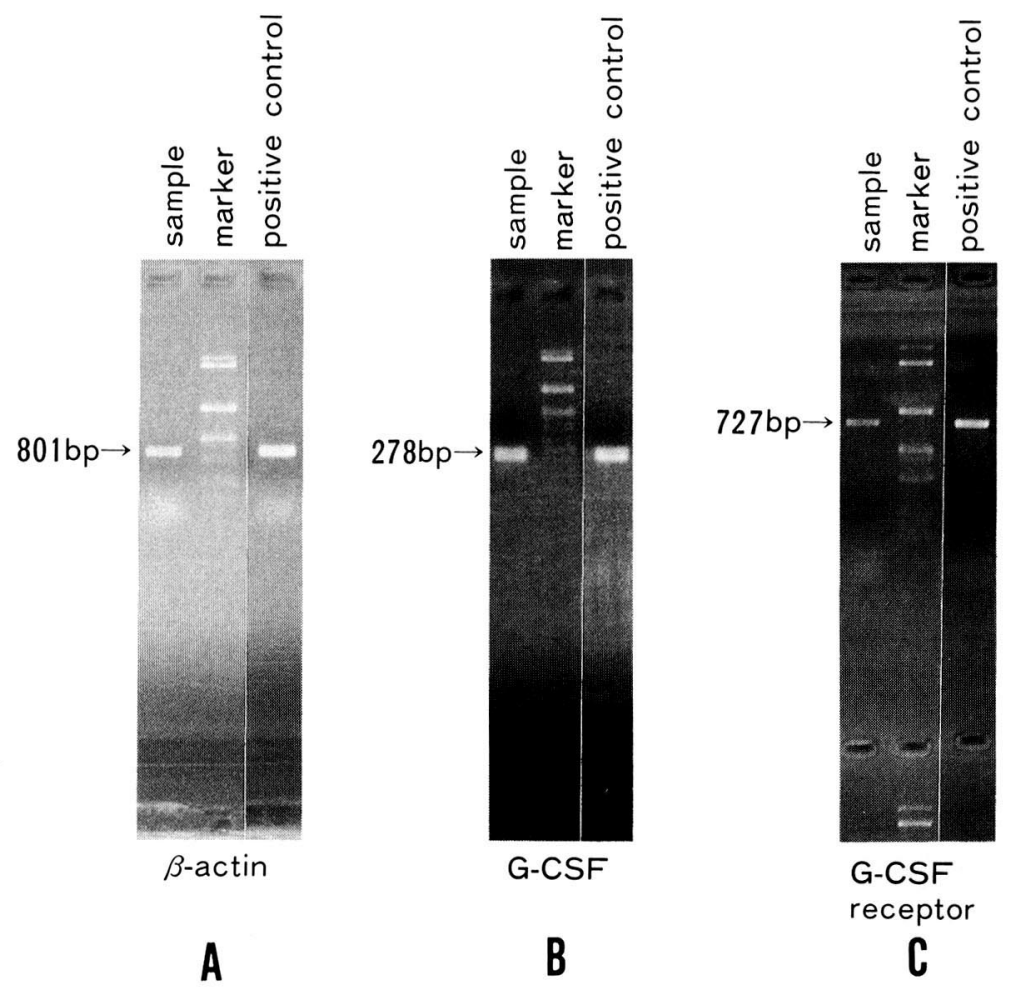

著であり ${ }^{87)}$ ここの EGF-R の遺伝子は chromosome 7に 存在し88)さらに chromosome 70 hyperploidy は浸潤 性移行上皮癌における最も頻度の高い cytogenetic な 所見である点であろう ${ }^{89)}$. また, Sauter らは ${ }^{90)}$, 膀胱 癌における EGF-R の発現と腫瘍の増殖性との関連を BrdU 標識率により検討し, EGF-R の発現と BrdU 標 識率とに強い相関を認め, 膀胱癌増殖性と EGF-R 発 現との関連を指摘している。

以上のように EGF あるいは EGF-R は他の癌種と 同様膀胱癌においてもその増殖・進展に関連している 可能性が高いが，より詳細なその機序の解明が今後の 臨床的有用性を高める上で必要であると考えられる。

細胞増殖をコントロールする液性因子には前述の EGF のように細胞の増殖を促進する因子と, 逆に制御 因子としての増殖抑制因子が存在し，その代表として transforming growth factor $\beta$ (TGF- $\beta$ ) が挙げられ $3^{91) \sim 93)}$. Cooms ら ${ }^{94)}$ は 7 種類の膀胱癌培養細胞株と 40 例の膀胱癌症例に対し TGF- $\beta$ の mRNA 発現を Northern blotting により解析し, TGF- $\beta 1$ 発現の隇少
した群はその発現が正常な群に比し予後が不良であっ たことより TGF- $\beta 1$ の発現と予後が関連する可能性を 示している.

つぎに癌細胞は各種のサイトカインを産生する可能 性が多く報告されている ${ }^{951 ~ 97)}$. 膀胱癌では granulocyte-colony stimulating factor (G-CSF) が 膀胱癌細胞より cloning され注目されている72). 一般 的には G-CSF 産生膀胱癌の場合, 著明な白血球增多 症を伴い, この腫瘍随伴症状を伴う症例の予後は通常 極めて不良であり, また腫晹の急速な進展増殖を来し たような時期と一致することが多い ${ }^{78) 79 ! 。 こ の よ う な ~}$ 臨床的事実を考えると腫瘍産生の G-CSF が腫湟自体 の増殖を促す autocrine growthを強く予想させるも のである.

著者らはヒト膀胱癌由来培養細胞株における GCSF receptorの発現を ${ }^{125}$ 標識 G-CSFを使用した receptor 結合試験により解析し，KU-1およびNBT-2 細胞に G-CSF に対する機能的受容体の存在を報告し た ${ }^{99)}$.これら細胞においては 1 〜 $500 \mathrm{ng} / \mathrm{ml}$ 濃度の $\mathrm{G}$ - 
CSF の添加によりその ${ }^{3} \mathrm{H}$-thymidine の取り込みが有 意に増加し G-CSFによる増殖性の圥進が示唆され た。一方, ごく最近, 著者らは G-CSF 産生膀胱癌細胞 の樹立に成功し, この細胞における増殖機序を研究し たところ, 本細胞は RT-PCR 法により G-CSF, G-CSF receptor 両者の mRNA を発現し, 外因性 G-CSF によ りその増殖が六進し, autocrine growth を示している ことが証明された ${ }^{100)}$.このことは, 膀胱癌細胞におけ る癌の進展発育に各種増殖因子が関連する可能性を示 唆するものであり, 今後これら増殖因子あるいはその receptor の発現機序の解明とともに癌細胞の特性解 明上興味あるものと考えられれる。

また,さらに最近の知見としてこれら各種サイトカ インが癌細胞における ICAM-1あるいは integrineな どの細胞接着分子の発現を増強させることが報告さ $れ^{101102)}$, 癌の浸潤・転移とも関連し興味ある今後の研 究課題であると考える.

なお，接着因子に対する分子生物学的アプローチに よる癌の進展・転移に関しては香川による詳細な review がなされているので参照されたい年3.

\section{癌遺伝子と癌抑制遺伝子}

膀胱移行上皮癌は他の多くの固型癌と同様に遺伝子 レベルでの異常による癌の進展が予想されてい る ${ }^{104) 105)}$.これらは癌遺伝子の変化あるいは増幅とし てとらえられるほか癌抑制遺伝子の変化, 転座あるい は欠失による不活化が知られている. 泌尿器科癌に関 する分子生物学の詳細はYoshida ${ }^{106)}$ により詳細な review が発表されているので,ここではごく簡単に膀 胱癌浸潤性との関連についてのみ述べることとする。

ヒト膀胱癌細胞においては EJ/T24細胞の H-ras 癌 遺伝子の変化が発見され ${ }^{107)}$, その後の各種癌における 癌遺伝子研究の発端となった。しかしながら, 膀胱癌 における ras 遺伝子の変異の発見率は $10 \%$ 以下である のが現在までの研究の結論である ${ }^{108)}$. 最近では c-erb B-2/neu oncogene が重点的に研究されている ${ }^{1099}$. な ぜなら, c-erb-2 oncogene が重点的に研究されてい る ${ }^{109)}$ ・なぜなら, c-erb-2 oncogene は epidermal growth factor receptor (EGF-R) と密接に関連する ことが判明したためである.

Wright $ら^{110)}$ は膀胱癌において c-erbB-2/neuの蛋 白の過剩発現を報告している。また Sato ら ${ }^{111}$ は cerbB-2 oncogene を免疫組織化学およびWestern blotting で分析し，54例中17例に c-erbB-2産物の発現 が認められこれは high-grade, high-stage の症例, な
らびにリンパ節転移症例に高率に認められたとしてい る.

その他，c-myc の methylation における過剰発現あ るいは変化の報告があるが12), 現時点ではその真の役 割は明らかでない。

一方, chromosome 17P の LOH は多くの腫場にお いて存在し, 大腸癌における先駆的研究では進行大腸 癌の大多数においてこのことが認められている ${ }^{113)}$. p53遺伝子はこの chromosome 17p に存在し, 多くの 大腸癌およびほほ全ての癌種において 553 変異が報 告されている114)115)。p53蛋白は, SV40 large T 抗原 と特異的に結合する細胞由来の核内リン酸化蛋白（分 子量 $53 \mathrm{kDa})$ として見い出され, 当初トランスフォーム した細胞にその発現が認められることより p53遺伝子 は oncogene と考えられていた。 その後の研究により 正常型 (野生型) p53蛋白は細胞のトランスフォーメー ションを阻害し，むしろ癌化を抑制する機能を有する 癌抑制遺伝子として位置付けられた ${ }^{116)}$. 膀胱癌におい

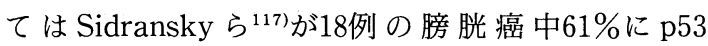
gene mutation が存在したことを最初に報告し，この 変異は high-stage, high-grade の腫瘍に認められ, 表 在性腫瘍においては稀であることを報告しており，こ れを支持する報告が多( ${ }^{118) 1199}$.

Uchida ら ${ }^{120)}$ は43例の膀胱癌症例に対する chromosome $17 \mathrm{p}$ と $\mathrm{p} 53$ gene mutation を検討し，50\%に17 p13の LOH を認め, その $90 \%$ pT2以上の症例であっ たとしている.一方, p53 gene mutation は43例中20 例 (46.5\%) に認め，その $95.0 \%$ はrade-2以上の悪性 度であり, 85\%は pT2以上の症例であり, high-grade, high-stage の症例で高率にその mutation が存在した としている。ささに彼らは, p53 gene mutation の有 無による予後を検討し, p53 mutation の無い群の 5 年 生存率は79.4\%であったのに対し, p53 mutation の存 在した群のそれは $33.3 \%$ あり p53 mutationの有無 は膀胱癌予後因子としても重要であるとしている．著 者らの教室においても再発例の表在性膀胱癌における p53 gene の mutation を PCR-SSCP 法により解析す ると30例の膀胱腫瘍における検討で 4 例にp53の mutation が存在し, その内 3 例が再発を来し,さらに 2 例は筋層浸潤癌に進展しており, 表在性腫瘍におい ても p53 gene の mutation が存在する膀胱腫瘍の予 後は不良であることが認められている ${ }^{121}$.

Mutant p53蛋白は正常型の p53蛋白に比し, 長い半 減期を有しており，免疫組織染色で容易に判定しえる 
ことが報告されている ${ }^{122)}$. 一方，免疫組織学的 $\mathrm{p} 53$ 蛋 白の同定は p53 gene の missense mutation に対する 検査法としては有用であるが，p53の gene nonsense mutation に対しては同定が困難であり, 免疫組織化学 的手法だけで p53 gene の変異を解析することは理論 上限界があるように考えられる。今後さらなる解明が 進み膀胱癌浸潤性と癌抑制遺伝子とのより密接な関連 が明らかになることが期待される.

\section{おわりに}

以上, 膀胱癌の浸潤性, 進展に関連する細胞生物学 的要因を中心に論じて来た。これら要因は多岐にわた り本稿においてその全てを論ずることは不可能であ る. Molecular biology が膀胱癌の発生ならびに進展 に関する理解に大きなインパクトをもたらすであろう ことが予想される.事実 Vogelstein らのグループは大 腸癌における発癌と進展における遺伝子変化を詳細に 明らかにしている，現状では膀胱癌で同様な変化を明 かにすることは困難であるが，これら変化に関する知 見は新たな技術の開発とともに日進月歩で発展してい る.これら個々の発見は即座に診断・治療につながる ものではないが, これらの努力が最終的には画期的な 発見へのステップとなるものと期待される.

\section{文献}

1) Russell, P., Raghavan, D., Philips, J. and Wills, E.J.: The biology of urothelial cancer. In the management of bladder cancer. Edited by Raghavan, D., pp. 1-41, 1988. Edward Arnold (Publishers) Ltd.

2) Liu, B.C.-C. and Liotta, L.A. : Biochemistry of bladder cancer invasion and metastasis (clinical implication). Urol. Clin. North Am., 19, 621627, 1992.

3) Heney, N.M.: Natural history of superficial bladder cancer. Urol. Clin. North Am., 19, 429 -433, 1992.

4) Kaye, K.W. and Lange, P.H. : Mode of presentation of invasive bladder cancer: Reassessment of the problem. J. Urol., 128, 31-33, 1982.

5) Heney, N.M., Ahmed, S., Flanagan, M.J., Frable, W., Corder, M.P. and Hafermann, M.D.: Superficial bladder cancer: Progression and recurrence. J. Urol., 130, 1083-1086, 1983.

6) Birch, B.R.P. and Hartland, S.J.: Review: The pT1 G3 bladder tumor. Br. J. Urol., 64, 109 -116, 1989.

7) Smith, G., Elton, R.A., Chisholm, G.D., Newsam, J.E. and Hargreave, J.B.: Superficial bladder cancer: Intravesical chemotherapy and tumor progression to muscle invasion or metastasis. Br. J. Urol., 58, 659-663, 1986.

8) Malmström, P., Busch, H. and Norlén, B.J.: Recurrence, progression and survival in bladder cancer. Scand. J. Urol. Nephrol., 21, 185-195, 1987.

9) Abel, P.D., Hall, R.R. and Williams, G. : Should pT1 transitional cell cancers of the bladder be classified as superficial ? Br. J. Urol., 62, 235-239, 1988.

10) Kakizoe, T., Fair, W.R., Smith, P.H., Algaba, F., Ferrari, P., Grossman, H.B., Zirkali, Z., Tsukamoto, T., Tachibana, M.: Grossman, H. B., Zirkali, Z., Tsukamoto, T., Tachibana, M.: What is the biology of invasion and metastasis in bladder cancer? Int. J. Urol., 2 (Suppl. 2), 58 $-63,1995$.

11) Gibas, Z., Prout, G.R. Jr., Conolly, J.G.Pontes, J. E. and Sandberg, A.A.: Non-random chromosomal changes in transitional cell carcinoma of the bladder. Cancer Res., 44, 12571264, 1984.

12) Fearon, E.R., Feinberg, A.O. and Hamilton, S. R. : Loss of genes on the short arm of chromosome 11 in bladder cancer. Nature, 318, 377380, 1985.

13) Tsai, Y.C., Nichols, P.W., Hiti, A.L., Williams, Z., Skinner, D.G. and Jones, P.A. : Alleic losses of chromosome 9, 11, and 17 in human bladder cancer. Cancer Res., 50, 44-47, 1990.

14) Olumi, A.F., Tsai, Y.C., Nichols, P.W., Skinner, D.G., Cain, D.R. : Alleic loss of chromosome $17 \mathrm{p}$ distinguishes high grade from low grade transitional cell carcinomas of the bladder. Cancer Res., 50, 7081-7083, 1990.

15) Gibas, Z. and Sandberg, A.A.: Chromosomal rearrngement in bladder cancer. Urology, 33(Suppl.), 3-9, 1984.

16) Nemoto, R., Nakamura, I., Uchida, K. and Harada, M.: Numerical chromosome aberrations in bladder cancer detected by in situ hybridization. Brit. J. Urol., 75 : 470-475, 1995.

17) Hopman, A.H.N., Moesker, O., Smeets, A.W.G. B., Pauwels, R.P.E., Vooijs, G.P. and Ramaekers, F.C.S.: Numerical chromosome 1,7,9, and 11 aberration in bladder cancer detected by in situ hybridization. Cancer Res., 51, 644-651, 1991.

18) Waldman, F.M., Carroll, P.R., Kerschmann, R., Cohen, M.B., Field, F.G. and Mayall, B.H.: Centroletric copy number of chromosome 7 is strongly correlated with tumor grade and labe- 
ling index in human bladder cancer. Cancer Res., 51, 3807-3813, 1991.

19) Helander, K., Hofer, P.A. and Holmberg, G. : Karyometric investigations on urinary bladder carcinoma correlated to histological grading. Virchows Arch. (A), 403, 117-125, 1984.

20) Lipponen, P.K., Eskelinen, M.J. and Sotarauta, M. : Prediction of superficial bladder cancer by histoquantitative methods. Eur. J. Cancer, 26, 1060-1063, 1990.

21) Lipponen, P. and Eskelinen, M. : Nuclear morphometry in grading transitional cell blad der cancer compared with subjective histological grading. Anticancer Res., 10, 17251730, 1990.

22) Blomjous, C.E.M., Schipper, N.W., Baak, J.P.A., Vas, W., de Voogt, H.J. and Meijer, C.J.: The value of morphometry and DNA flow cytometry in addition to classic prognosticators in superficial urinary bladder carcinoma. Am. J. Clin. Pathol., 91, 243-248, 1989.

23) Blomjous, C.E.M., Schipper, N.W., Baak, J.P.A., de Voogt, H.J. and Meijer, C.J.: Comparison of quantitative and classic prognosticators in urinary bladder carcinoma. Virchows Arch. (A), 415, 421-428, 1989.

24) Lipponen, P., Eskelinen, M. and Kiviranta, J. : Classic prognostic factor, flow cytometric data, nuclear morphometric variables and mitotic indexes as predictors in transitional cell bladder cancer. Anticancer Res., 11, 911-916, 1991.

25) Barlogie, B., Raber, M.N., Shumann, J., Johnson, T.S., Drewinko, B., Swartzendruber, D.E., Göhde, W., Andreeff, M. and Freireich, E.J. : Flow cytometry in clinical cancer research. Cancer Res., 43, 3982-3997, 1983.

26) Klein, F.A., Herr, H.W., Sogani, P.C., Whitmore, W.F. Jr. and Melamed, M.R. : Detection and follow-up of carcinoma of the urinary bladder by flow cytometry. Cancer, 50, 389-395, 1982.

27) Tribukait, B., Gustafson, H. and Esposti, P.L. : The significance of ploidy and proliferation in the clinical and biological evaluation of bladder tumours: A study of 100 untreated cases. Brit. J. Urol., 54, 130-135, 1982.

28) Lipponen, P.K., Eskelinen, M.J. and Nordling, S.: Progression and survival in transitional cell bladder cancer: A comparison of established prognostic factors, S phase fraction and DNA ploidy. Eur. J. Cancer, 27, 877-881, 1991.

29) Malmström, P.U., Norlen, B.J., Andersson, B. and Busch, C.: Combination of blood group
$\mathrm{ABH}$ antigen status and DNA ploidy as independent prognostic factor in transitional cell carcinomas. Scand. J. Urol. Nephrol., 64, 4955, 1989.

30) Shaaban, A.A., Tribukait, B., El-Bedeiwy, A.F. A. and Ghoneim, M.A. : Prediction of lymph node metastasis with deoxyribonucleic acid flow cytometry. J. Urol., 144, 884-887, 1990.

31) Tribukait, B.: Flow cytometry in assessing the clinical aggressiveness of genitourinary neoplasms. World J. Urol., 5, 108-122, 1987.

32) Masters, J.R.W., Camplejohn, R.S., ConstancePerkinson, M. and Woodhouse, C.R.: DNA ploidy and the prognosis of stage pT1 bladder cancer. Br. J. Urol., 64, 403-408, 1989.

33) Blomjous, C.E., Schipper, N.W., Baak, J.P.A., van Galen, E.M., de Voogt, H.J. and Meyer, C. J.: Retrospective study of prognostic importance of DNA flow cytometry of urinary bladder carcinoma. J. Clin. Pathol., 41, 21-25, 1988.

34) Murphy, W.M., Chandler, R.W. and Trafford, R. M. : Flow cytometry of deparaffinized nuclei compared to histological grading for the pathological evaluation of transitional cell carcinomas. J. Urol., 135, 694-697, 1986.

35) Pauwels, R., Smeets, A., Schapers, R. and Beck, H.: Are cytoflowmetry or chromosome studies or other predictors of any help determining the prognosis of low-grade superficial tumors? Prog. Clin. Biol. Res., 303, 503-510, 1989.

36) deVere White, R.W., Deitch, A.D., West, B. and Fitzpatrick, J.M.: The predictive value of flow cytometric information in the clinical management of stage $\mathrm{O}(\mathrm{Ta})$ bladder cancer. J. Urol., 139, 279-282, 1988.

37) Tachibana, M., Deguchi, N., Baba, S., Jitsukawa, S., Hata, M. and Tazaki, H.: Multivariate analysis of flow cytometric deoxyribonucleic acid parameters and histological features for prognosis of bladder cancer patients. J. Urol., 146, 1530-1534, 1991.

38）吉川和行：Flow cytometry による膀胱腫瘍の研 究. 第 2 報. Flow cytometric DNA analysis に よる膀胱腫瘍の予後と腔内再発の解析. 日泌尿会 誌, 78, 227, 1987.

39) Lipponen, P.K., Eskelinen, M.J. and Nordling, S.: Intratumoral heterogeneity of DNA indices in transitional cell bladder cancer: Relation to tumor histology. Eur. Urol., 20, 311314, 1991.

40) Kirkhus, B., Clausen, O.P.F., Fjordvang, H. and 
Helander, K.: Characterization of bladder tumors by multiparameter flow cytometry with special reference to grade II tumors. A.P.M.I.S., 96, 783-792, 1988.

41) Wheeless, L.L., Badalament, R.A., deVere White, R.W., Fradet, Y. and Tribukait, B.: Consensus review of the clinical utility of DNA cytometry in bladder cancer. Cytometry, 14, 478-481, 1993.

42) Meyer, J.S.: Growth and cell kinetic measurements in human tumors. Pathol. Annual., 16 (pt2), 53, 1981.

43) Gratzner, H.G.: Monoclonal antibody to 5bromo- and 5-iododeoxyuridine: A new reagent for detection of DNA replication. Science, 218, 474-475, 1982.

44) Danova, M., Wilson, W., Riccardi, A., Mazzini, G., Ucci, G., Giordano, M., Brugnatelli, S., Luoni, R., McNally, N.J. and Ascari, E.: In vivo administration of bromodeoxyuridine and flow cytometry for cell kinetic studies in human malignancies. Haematologica, 72, 115-119, 1987.

45) Dolbeare, F., Gratzner, H., Pallavicini, M.G. and Gray, J.W.: Flow cytometric measurement of total DNA content and incorporated bromodeoxyuridine. Proc. Natl. Acad. Sci. U.S. A., 80, 5573, 1983.

46) Nishizaki, T., Orita, T., Furutani, Y., Ikeyama, Y. and Aoki, H. : Flow-cytometric DNA analysis and immunohistochemical measurement of $\mathrm{Ki}-67$ and BUdR labeling indices in human brain tumors. J. Neurosurg., 70, 379-384, 1989.

47) Tachibana, M., Deguchi, N., Jitsukawa, S., Baba, S., Hata, M. and Tazaki, H.: Quantification of cell kinetic characteristics using flow cytometric measurements of deoxyribonucleic acid and bromodeoxyuridine for bladder cancer. J. Urol., 145, 963-967, 1991.

48) Tachibana, M., Deguchi, N., Baba, S., Jitsukawa, S., Hata, M. and Tazaki, H. : Prognostic significance of bromodeoxyuridine high-labeled bladder cancers measured by flow cytometry: Dose flow cytometric determination predict the prognosis of patients with transitional cell carcinoma of the bladder? J. Urol., 149, 739-743, 1993.

49) Miyakawa, M., Tachibana, M. and Tazaki, H.: Flow cytometric measurements of deoxyribonucleic acid ploidy and proliferative activity for evaluating malignant potential of human bladder cancers. Cancer Detection and Preven- tion, 19, 165-172, 1995.

50) Tachibana, M., Miyakawa, A., Deguchi, N., Baba, S., Murai, M. and Tazaki, H.: New scoring system based on the histological behavior and proliferative activity of tumor cells for grading the malignant potential of bladder cancers. Int. J. Urol., 1, 37-42, 1994.

51) Miyachi, K., Fritzler, M.J. and Tan, E.M.: Autoantibody to a nuclear antigen in proliferating cells. J. Immunol., 121, 2228-2234, 1978.

52) Woods, A.L., Hall, P.A. and Shepherd, N.A.: The assessment of proliferating cell nuclear antigen (PCNA) immunostaining in primary gastrointestinal lymphomas and its relationship to histological grade, $\mathrm{S}+\mathrm{G} 2+\mathrm{M}$ phase fraction (flow cytometric analysis) and prognosis. Histopathology, 19, 21-27, 1991.

53) Lipponen, P.K. and Eskelinen, M.J.: Cell proliferation of transitional cell bladder tumors determined by PCNA/cyclin immunostaining and its prognostic value. Br. J. Cancer, 66, 171 -176, 1992.

54) Hattori, K., Uchida, K., Akaza, H., Koiso, K., Nemoto, R. and Harada, M.: Proliferating cell nuclear antigen cyclin in human transitional cell carcinoma. Br. J. Urol., 75, 162-166, 1995.

55) Gerdes, J., Lemke, H., Baisch, H., Wacker, H. H., Schwab, U. and Stein, H.: Cell cycle analysis of a cell proliferation-associated human nuclear antigen defined by the monoclonal antibody Ki-67. J. Immunol., 133, 1710, 1984.

56) Gerdes, J., Schwab, U., Lemke, H. and Stein, H. : Production of a mouse monoclonal antibody reactive with a human nuclear antigen associated with cell proliferation. Int. J. Cancer, 31, 13, 1983.

57) Fontana, D., Bellina, M., Gubetta, L., Fasolis, G., Rolle, L., Scoffone, C., Porpiglia, F., Colombo, M., Tarabuzzi, R. and Leonardo, E.: Monoclonal antibody Ki-67 in the study of the proliferative activity of bladder carcinoma. J. Urol., 148, 1149-1151, 1992.

58) Tsujihashi, H., Nakanishi, A., Matsuda, H., Uejima, S. and Kurita, T.: Cell proliferation of human bladder tumors determined by BRDURD and Ki-67 immunostaining. J. Urol., 145, 846-849, 1991.

59) Bush, C., Price, P. and Norton, J.: Proliferation in human bladder carcinoma measured by Ki-67 antibody labeling: Its potential clinical importance. Br. J. Cancer, 64, 357-360, 1991. 
60) Derenzini, M., Pession, A., Farabegoli, F., Tere, D., Badiali, M. and Dehan, P.: Relationship between interphasic nuclear organizer regions and growth rate in two neuroblastoma cell lines. Am. J. Pathol., 134, 925-932, 1989.

61) Lipponen, P.K., Eskelinen, M.J. and Nordling, S. : Nucleolar organiser regions as prognostic factors in transitional cell bladder cancer. Br. J. Cancer, 64, 1139--1144, 1991.

62) Lipponen, P.K. and Eskelinen, M.J.: Argyrophilic nucleolar organiser regions (Ag-NORs) in transitional cell bladder tumours related to established prognostic factors. Progression and independent prognostic value. Oncology, 49, 152 -157, 1992.

63) Lipponen, P., Eskelinen, M. and Syrjanen, S. : The use of immunohistochemically demonstrated c-erb B-2 oncoprotein expression as a prognostic factor in transitional cell carcinoma of the urinary bladder. Eur. Urol., 20, 238-242, 1991.

64) Cohen, M.B., Waldman, F.M., Carroll, P.R., Kerschmann, R., Chew, K. and Mayall, B.H. : Comparison of five histopathologic methods to assess cellular proliferation in transitional cell carcinoma of the urinary bladder. Hum. Pathol., 24, 772-778, 1993.

65) Iles, R.K., Oliver, R.T.D., Kitau, M., Walker, C. and Chard, T.: In vitro secretion of human chorionic gonadotropin by bladder tumour cells. Br. J. Cancer, 55, 623-626, 1987.

66) Kinjo, M., Oka, K., Naito, S., Kohga, S., Tanaka, K., Oboshi, S., Hayata, Y. and Yasumoto, K. : Thromboplastic and fibrinolytic activities of cultured human cancer cell lines. Br. J. Cancer, 39, 15-23, 1979.

67) Chodak, G.W. and Summerhayes, I.: Detection of angiogenesis activity in malignant bladder tissue cells. J. Urol., 132, 1032-1035, 1984.

68) Droller, M.J., Perlmann, P. and Schneider, M. U. : Enhancement of natural and antibodydependent lymphocyte cytotoxicity by drugs which inhibit prostaglandin production by tumor target cells. Cellular Immunology, 39, 154-164, 1979.

69) Hall, R.R., Laurence, D.J.R., Munro, A. and Wallace, D.M.: Carcinoembryonic antigen and urothelial carcinoma. Br. J. Urol., 45, 8892, 1973.

70) Russell, P., Raghavan, D. and Gregory, P.: Bladder cancer xenografts: A model of tumor cell heterogeneity. Cancer Res., 46, 2035-2040,
1986.

71) Christie, J.F., Gallagher, G. and Stimson, W.H. : The human bladder carcinoma line T-24 secretes a human B-cell differentiation factor. Immunology, 60, 467-469, 1987.

72) Welte, K., Platzar, E., Lu, L., Gabrilove, J.L., Levi, E., Mertelsmann, R. and Moore, M.A.S. : Purification and biochemical characterization of human pluripotent hematopoietic colonystimulating factor. Proc. Natl. Acad. Sci. U.S. A., 82, 1526-1530, 1985.

73) Sato, K., Terada, K., Sugiyama, T., Matsuda, H., Kakinuma, H. and Kato, T.: Granulocyte colony-stimulating factor produced by bladder carcinoma of a patient with leukemoid reaction did not affect proliferation of the tumor cells. J. Urol., 151, 1687-1690, 1994.

74) Shah, V., Newman, J., Crocker, J.M., Chapple, C.R., Collard, M.J., O'Brien, J.M. and Considine, J.: Ectopic $\beta$-human chorionic gonadotropin production by bladder urothelial neoplasia. Arch. Pathol. Lab. Med., 110, 107-111, 1986.

75) Campo, E., Algaba, F., Palacin, A., Germa, R., Sole-Balcells, F.J. and Cardesa, A.: Placental proteins in high-grade urothelial neoplasms: An immunohistochemical study of human chorionic gonadotropin, human placental lactogen, and pregnancy-specific beta-1-glycoprotein. Cancer, 63, 2497-2504, 1989.

76) Dexeus, F., Logothetis, C., Hossan, E. and Samuels, M.L.: Carcinoembryonic antigen and beta-human chorionic gonadotropin as serum markers for advanced urothelial malignancies. J. Urol., 136, 403-407, 1986.

77) Smith, D.J., Evans, H.J., Newman, J. and Chapple, C.R.: Ectopic human chorionic gonadotropin (HCG) production: Is the detection by serum analysis of HCG of clinical relevance in transitional cell carcinoma of the bladder. Br. J. Urol., 73, 409-412, 1994.

78) Cohen, S. : Epidermal growth factor. In Vitro Cell Dev. Biol., 23, 239-242, 1987.

79) Gregory, H.: Isolation and structure of urogastrone and its relationship to epidermal growth factor. Nature, 259, 325-327, 1975.

80) Drucker, B.J., Mamon, H.J. and Robert, T.M. : Oncogenes, growth factors, and signal transduction. N. Engl. J. Med., 321, 1383-1391. 1989.

81) Kuranami, M., Yamaguchi, K., Fuchigama, M., Imanishi, K., Watanabe, T., Abe, K., Asanuma, F. and Hiki, Y.: Effect of urine on clonal growth of human bladder cancer cell lines. 
Cancer Res., 51, 4631-4635, 1991.

82) Momose, H., Kakinuma, H., Shariff, S., Mitchell, G.B., Rademaker, A. and Oyasu, R. : Tumor promoting effects of urinary epidermal growth factor in rat urinary bladder carcinogenesis. Cancer Res., 51, 5487-5490, 1991.

83) Yura, Y., Hayashi, O., Kelly, M. and Oyasu, R. : Identification of epidermal growth factor as a component of rat urinary bladder tumorenhancing urinary factions. Cancer Res., 49, 1548-1553, 1989.

84) Sidransky, D. and Messing, E.M. : Molecular genetics and biochemical mechanisms in bladder cancer. Urol. Clin. North Am., 19, 629-639, 1992.

85) Neal, D.A. and Mellom, K. : Epidermal growth factor receptor and bladder cancer: A review. Urol. Int., 48, 365-371, 1992.

86) Messing, E.M. : Clinical implications of the expression of epidermal growth factor receptors in human transitional cell carcinoma. Cancer Res., 50, 2530-2537, 1990.

87) Smith, K., Fennelly, J.A., Neal, D.E., Hall, R.R. and Harris, A.L.: Characterization and quantification of the epidermal growth factor receptor in invasive and superficial bladder tumors. Cancer Res., 49, 5810-5815, 1989.

88) Shimizu, M.I., Kondo, I., Gamous, S., Behzadian, M.A. and Shimizu, Y.: Genetic analysis of hyperproduction of epidermal growth factor receptors in human epidermoid carcinoma A 431 cells. Somat. Cell Mol. Genet., 10, 45-53, 1984.

89) Waldman, F.M., Carroll, P.R., Chew, K., Field, F., Germain, L. and Mayall, B.: Interphase cytogenetics and proliferative activity in bladder carcinoma (abstruct). J. Urol., 145, 248A, 1991.

90) Sauter, G., Haley, J., Chew, K., Kerschmann, R., Moore, D., Carroll, P., Moch, H., Gudat, F., Mihatsch, M.J. and Waldman, F.: Epidermal growth factor receptor expression is associated with rapid tumor proliferation in bladder cancer. Int. J. Cancer, 57, 508-514, 1994.

91) Moses, H.L., Yang, Y.E. and Pietenpol, J.A. : TGF- $\beta$ stimulation and inhibition of cell proliferation: New mechanistic insights. Cell, 63, 245 $-247,1990$

92) Jatten, A.M., Shirley, J.E. and Stoner, G. : Regulation of proliferation and differentiation of respiratory tract epithelial cells by TGF- $\beta$. Exp. Cell Res., 167, 539-549, 1986.
93) Kurokawa, M., Lynch, K. and Podolsky, D.K. : Effects of growth factors on an intestinal epithelial cell line: TGF- $\beta$ inhibits proliferation and stimulates differentiation. Biochem. Biophys. Res. Commun., 142, 775-782, 1987.

94) Cooms, L.M., Pigott, D.A., Eydmann, M.E., Proctor, A.J. and Knowles, M.A.: Reduced expression of TGF- $\beta$ is associated with advanced disease in transitional cell carcinoma. Br. J. Cancer, 67, 578-584, 1993.

95) de Reijke, T.M., Vos, P.C.N., de Boer, E.C., Bevers, R.F.M., de Muinck-Keizer, W.H., Kurth, K.H. and Schamhart, D.H.J.: Cytokine production by the human bladder carcinoma cell line T24 in the presence of bacillus CalmetteGuerin (BCG). Urol. Res., 21, 349-352, 1993.

96) Hedges, S., Agace, W., Svensson, M., Sjögren, A., Ceska, M. and Svanborg, C. : Uroepithelial cells are part of a mucosal cytokine network. Infect. Immun., 62, 2315-2321, 1994.

97) Kaashock, J.G.J., Mout, R., Falkenburg, J.H.F., Willemze, R., Fibbe, W.E. and Landegent, J.E. : Cytokine production by the bladder carcinoma cell line 5637 : Rapid analysis of mRNA expression levels using a cDNA-PCR procedure. Lymphokine Cytokine Res., 10, 231-235, 1991.

98) Sires, C., Neely, S. and Skinner, D.: Leukemoid reaction in a patient with bladder and prostatic cancer. J. Urol., 135, 366-367, 1986.

99) Ohigashi, T., Tachibana, M., Tazaki, H. and Nakamura, K. : Bladder cancer cells express functional receptors for granulocyte-colony stimulating factor. J. Urol., 147, 283-286, 1992.

100) Tachibana, M., Miyakawa, A., Tazaki, H., Nakamura, K., Kubo, A., Hata, J., Nishi, T. and Amano, Y.: Autocrine growth of transitional cell carcinoma of the bladder induced by granulocyte-colony stimulating factor. Cancer Res., 55, 3438-3443, 1995.

101) Vitolo, D., Palmieri, B.M., Ruco, L.P., Rendina, E., Bonsignore, G. and Baroni, C.D. : Cytokine production and expression of adhesion molecules and integrins in tumor infiltrating lymphomononuclear cells of non-small cell carcinoma of the lung. Am. J. Pathol., 145, 322329, 1994.

102) Bernasconi, S., Matteucci, C., Sironi, M., Conni, M., Colotta, F., Mosca, M., Colombo, N., Bonazzi, C., Landoni, F., Corbrtte, G., Mantovani, A. and Allavena, P.: Effects of granulocytemonocyte colony-stimulating factor (GM-CSF) on expression of adhesion molecules and pro- 
duction of cytokines in blood monocytes and ovarian cancer-associated macrophages. Int. J. Cancer, 60, 300-307, 1995.

103）香川 征：泌尿器科腫瘍学に扔ける分子生物学. 日泌尿会誌，86，963-978，1995.

104) Weinberg, R.A.: Oncogenes, antioncogens, and the molecular bases of multistep carcinogenesis. Cancer Res., 49, 3713-3721, 1989.

105) Bishop, J.M.: The molecular genetics of can cer. Science, 235, 305-311, 311, 1987.

106) Yoshida, O., Habuchi, T. and Ogawa, O.: Recent advances in the molecular genetics of urogenital tumors. Int. J. Urol., 1, 1-16, 1994.

107) Reddy, E.P., Reynolds, R.K., Santos, E. and Barbacid, M.: Reddy, E.P., Peynolds, R.K., Santos, E. and Barbacid, M.: A point mutation is responsible for the acquisition of transforming properties of the T-24 human bladder carcinoma oncocogene. Nature, 300, 149-152, 1982.

108) Fujita, J., Srivasta, S.K., Kraus, M.H., Rhim, J. S., Tronick, S.R. and Aaronson, S.A.: Frequency of molecular alterations affecting ras protooncogenes in human urinary tract tumors. Proc. Natl. Acad. Acad. Sci. U.S.A., 82, 3849-3853, 1985.

109) Slamon, D.J., Clark, S.G., Wong, W.J., Levin, W. J., Ullrich, A. and McGuire, W.L.: Human breast cancer: Correlation of relapse and survival with amplification of the Her-2/neu oncogene. Science, 235, 177-182, 1987.

110) Wright, C., Mellon, K., Neal, D.E., Johnston, P., Corbett, I.P. and Horne, C.H.: Expression of c-erb B-2 protein product in bladder cancer. Br. J. Cancer, 62, 764-765, 1990.

111) Sato, K., Moriyama, M., Mori, S., Saito, M., Watanuki, T., Terada, K., Okuhara, E., Akiyama, T., Toyoshima, K., Yamamoto, T. and Kato, T.: An immunohistologic evaluation of C-erbB-2 gene product in patients with urinary bladder carcinoma. Cancer, 70, 24932498, 1992.

112) Masters, J.R., Vesey, S.G., Munn, C.F., Evan, G. I. and Watson, J.V.: C-myc oncoprotein levels in bladder cancer. Urol. Res., 16, 341-344, 1988.

113) Baker, S.J., Fearon, E.R., Nigro, J.M. : Hamilton, S.R., Preisinger, A.C., Jessup, J.M., van Tuinen, P., Ledbetter, D.H., Barker, D.F., Nakamura, Y.: Chromosome 17p deletion and p53 gene mutations in colorectal carcinoma Science, 244, 219-221, 1989.

114) Nigro, J.M., Baker, S.J., Preisinger, A.C., Jessup, J.M., Hostetter, R., Cleary, K., Bigner, S.H., Davidson, N., Baylin, S. and Devilee, P.: Mutations in the p53 gene occur in diverse tumor types. Nature, 342, 705-708, 1989.

115) Hollstein, M., Sidransky, D., Vogelstein, B., Harris, C.C.: p53 mutations in human cancer. Science, 253, 49-53, 1991.

116) Levine, A.J., Momand, J. and Finlay, C.A.: The p53 tumor suppressor gene. Nature, 351, 453-456, 1991.

117) Sidransky, D., Von Eschenbach, A., Tsai, Y.C., Jones, P., Summerhayes, I., Marshall, F., Paul, M., Green, P., Hamilton, S.R. and Frost, P.: Identification of $\mathrm{p} 53$ gene mutations in bladder cancers and urine samples. Science, 252, 706709, 1991.

118) Fujimoto, K., Yamada, Y., Okajima, E., Kakizoe, T., Sasaki, H., Sugimura, T. and Terada, M.: Frequent association of p53 gene mutation in invasive bladder cancer. Cancer Res., 52 , 1393-1398, 1992.

119) Habuchi, T., Takahashi, R., Yamada, H., Ogawa, O., Kakehi, K., Ogura, K., Hamazaki, S., Toguchia, J., Ishizaki, K., Fujita, J., Sugiyama, T. and Yoshida, O.: Influence of cigarette smoking and scistosomiasis on p53 gene mutation in urothelial cancer. Cancer Res., 53, 3795-3799, 1993.

120) Uchida, T., Wada, C., Ishida, H., Wang, C., Efawa, S., Yokoyama, E., Kameya, T. and Koshiba, K.: p53 mutations and prognosis in bladder tumors. J. Urol., 153, 1097-1104, 1995.

121) Yoshimura, I., Kudoh, J., Saito, S., Tazaki, H. and Shimizu, N.: p53 gene mutation in recurrent superficial bladder cancer. J. Urol., 151, 1711-1715, 1995.

122) Esrig, D., Spruck, C.H. III, Nichols, P.W., Chaiwun, B., Steven, K., Groshen, S., Vhen, S.-C., Skinner, D.G., Jones, P.A. and Cote, R.J. : p53 nuclear protein accumulation correlates with mutations in the p53 gene, tumor grade, and stage in bladder cancer. Am. J. Pathol., 143, 1389-1397, 1993. 